\title{
KRITIKNALAR TAFSIR SYI'RI
}

\author{
Aksin Wijaya \\ Dosen Ushuludin STAIN Ponorogo. Email: asawijaya@yahoo.com
}

\section{Abstract}

The article exposes the critique of Thoba Husein on the logical reasoning of syi'ri tafseer commonly used by several tafseer experts, such as al-Zarkasi, al-Suyuti, and al-Thabari. The logical reasoning of syi'ri tafseer developing until today states that Al-Qur'an was descended using Arabic language in which some of the verses refer to the Jahiliah syi'ir that existed in the Arab community at the time. Thoba Husein criticizes on the opinion. His argument is on the authenticity of jabiliyah syi'ir, not on the urgency of its usage to understand difficult words of Al-Qur'an. According to him, those are not really jabiliyah syi'ir, but they were made by plagiarists during Islamic era for bidden interest.

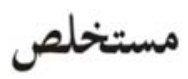

تقدم هذه المقالة قراءة لرؤية طه حسين حول ابحاه التفسير الشعري للقرآن كما يرد عند الزخشري والسيوطي والطبري وغيرهم. فمن وجهة نظر طه حسين تعوّد المفسرون على تفسير القر آن عبر إرجاع دلالاته إلى الدلالات الواردة في الشعر الجاهلي. ولا يعترض طه حسين على هذا الاتحاه من حيث المبدأ، إنما يعترض على مدى أصالة الشعر الجاهلي نفسه، الذي يراه إبداعاً تاريخياً إسلامياً تمت صياغته لخدمة أغراض معينة في تفسير القر آن. 


\section{A. Pendahuluan}

Dalam tipologi tafsir ${ }^{1}$ dan ulum Al-Qur'an tidak ditemukan istilah tafsir al-syi'ri. Yang ada hanyalah tafsir al-adabi. ${ }^{2}$ Namun jika kita melihat karya-karya tafsir Al-Qur'an yang beredar luas dalam dunia Islam mulai dari karya tafsir klasik sampai tafsir komtemporer, akan ditemukan banyak tafsir yang menggunakan syi'ir, khususnya syiir Arab Jahiliyah. ${ }^{3}$ Tafsir seperti ini secara sederhana bisa disebut sebagai tafsir al-Syi'ri.

Penggunaan syi'ir Jahiliyah dalam menafsiri Al-Qur'an didasarkan pada beberapa alasan. Selain karena Al-Qur'an dipahami sebagai respons terhadap perkembangan budaya syi'ir yang menguasai masyarakat Arab, penggunaan syi'ir dalam menafsiri Al-Qur'an juga didasarkan pada asumsi bahwa syi'ir Jahiliyah mencerminkan realitas kehidupan masyarakat Arab Jahiliyah, sehingga syi'ir itu bisa digunakan membantu memahamai istilah-istilah sulit dalam Al-Qur'an. Istilah-istilah sulit itu diasumsikan bisa dipahami dengan mudah jika menggunakan syi'ir Jahiliyah.

Syi'ir Jahiliyah bukan hanya diposisikan sebagai perangkat sekunder yang boleh dilupakan, sebaliknya telah menjadi alat primer, sehingga ketika muncul karya yang mengkritisi dan mempertanyakan otentisitas syi'ir Jahiliyah kemudian mendapat sorotan tajam. Toha Husein adalah salah satu pemikir muslim Mesir yang mempertanyakan otentisitas syi'ir Jahiliyah berikut urgensi penggunaannya dalam memahami al-Qur'an. Menurut dia, apa yang disebut syi'ir Jahiliyah sekarang ini tidaklah benar-benar murni syi'ir Jahiliyah, melainkan karya-karya belakangan yang diatasnamakan syi'ir Jahiliyah yang ditulis karena motif-motif tertentu, baik motif politik, agama, kisah, sosial kemasyarakatan, dan perawi. Karena itu, dia juga meragukan apa yang diduga sebagai syi'ir Jahiliyah itu bisa dijadikan pijakan dalam melihat realitas kehidupan masyaakat Arab Jahiliyah. Untuk memahami realitas masyarakat Jahiliyah menurut dia sejatinya kita merujuk langsung pada Al-Qur'an yang otentisitasnya tidak diragukan lagi.

1 Ignaz Gholdziher mencatat adanya lima kecenderungan tafsir atau studi Al-Qur'an mulai klasik sampai era modern, yakni studi Al-Qur'an tradisional, studi Al-Qur'an dogmatis, studi AlQur'an mistik, studi Al-Qur'an sektarian dan studi Al-Qur'an modern. Ignaz Gholdziher, Madzâhib al-Tafsir al-Islami, cet. Ke 2, (Beirut Libanun: Dar Iqra', 1983), hal. 392.

2 Kecenderungan tafsir modern dalam tipologi Ghaldziher, secara metodologis, oleh Jansen dibagi menjadi tiga model, yakni Tafsir Imi, Tafsir Realis (waqi'i) dan Tafsir Sastra (adabi). Jansen, Diskursus Tafsir Al-Qur'an Modern, terj. Hairussalim, dan Syrif Hidayatullah, (Yogyakarta: Tiara Wacana, 1997), hal. 125.

3 Tafsir al-Thabari, Tafsir al-Qurtubi, dan tafsir Ibnu Hatim misalnya banyak menggunakan apa yang disebut syi'ir jahiliyah. 
Argumen Husein dalam buku yang berjudul fi al-Syi'ri al-Jabili ini cukup menarik dikaji, karena buku ini bukan hanya hendak memprofankan syi'ir Jahiliyah yang selama ini telah disakralkan oleh para mufassir, tetapi juga hendak menjernihkan pandangan dunia Al-Qur'an dari kepentingan-kepentingan tertentu yang diselipkan dalam syi'ir Jahiliyah, dan juga agar masyarakat Jahiliyah mendapat pandangan obyektif yang selama ini dipahami salah oleh umat Islam. Pandangan obyektif terhadap mereka bisa ditemukan dalam al-Qur'an, karena Al-Qur'an menurut dia lepas dari susupan kepentingan.

\section{B. Background Intelektual}

Pada akhir abad XIX dan awal abad XX, iklim politik, sosial dan intelektual di Mesir mengalami perubahan besar. Dari segi politik, nasionalisme lagi menampakkan perannya, sebab pada saat itu Mesir lagi bergolak untuk melepaskan diri dari kesultanan Usmani dan jajahan ingris. Menurut Albert Hourani, sebagaimana dilansir Sahrin Harahap, ada tiga model nasionalisme yang berkembang di Mesir antara rentang waktu 1860-1914: pertama, religious nasionalism, nasionalime yang didasarkan pada kesamaan agama, kedua, ethnic/linguistic nasionalism, nasionalisme yang didasarkan pada kesamaan bangsa dan bahasa, ketiga, territorial patriotism, nasionalisme yang didasarkan pada kesamaan tempat. ${ }^{4}$

Dari segi kondisi sosialnya, Mesir pada abad ke XIX dan XX memasuki kondisi liberal. Itu ditandai dengan munculnya gagasan pemisahan antara agama dengan kebudayaan dan politik. Lahirlah perdebatan hangat tentang masuknya pemikiran barat ke Mesir tentang masalah ini. Sementara pemikir yang terpengaruh oleh pemikiran Barat menyarankan adanya pemisahan yang tegas antara agama dan dunia yang kemeudian disebut sekularisasi, para ulama tradisional menginginkan tidak adanya pemisahan. Agama dan dunia tidak boleh dipisah. Agama harus mewarnai dunia, kebudayaan, politik dan sebagainya.

Kondisi liberal Mesir ini kemudian melahirkan kebangkitan gerakan pemikiran yang kira-kira terbagi menjadi tiga trend: pertama, the Islamic trend, trend kembali kepada Islam yang dipelopori Rasyid Ridla (1865-1935) dan Hasan al-Banna (19061949), kedua, the syintetic trend, trend pemikiran yang memadukan Islam dengan barat yang dipelopori Muhammad Abduh, Qosim Amin (1865-1908), dan Ali Abdur

4 Syahrin Harahap, Al-Qur'an dan Sekularisasi: Kajian Kritis Terbadap Pemikiran Thaha Husein,(Yogyakarta: Tiara Wacana, 1994), hal. 21-22. 
Razik(1888-1966), ketiga, the rasional scientific and liberal trend, suatu trend pemkiran yang memiliki kecendrungan rasional ilmiyah dan liberal. Titik tolak trend terakhir ini adalah pemikiran barat murni dengan tokohnya Luthfy al-Sayyid. Menurut Sahrin, Husein masuk ke dalam ketiga kecendrungan itu dan terutama dipengaruhi oleh Muhammad Abduh, Qasim Amin dan luthfy al-Sayyid. ${ }^{5}$

Thaha Husein lahir pada th. 1889. Pada tahun 1902-1912 dia belajar di al-Azhar. Bersamaan dengan itu, dia juga belajar di Universitas Kairo pada tahun 1914. Selepas dari dua universitas bergengsi di Mesir itu, dia melanjutkan studinya ke Sorbone Prancis. Sekembalinya ke Mesir dari prancis pada tahun 1919, Husein menemukan negaranya sedang mengalami revolusi dalam rangka membebaskan diri dari jajahan ingris yang berlangsung sampai pada tahun 1921 dan berakhir dengan diserahakannya Mesir kepada putra Mesir bernama Sa'ad Zaghlul pemimpin partai Wafd.

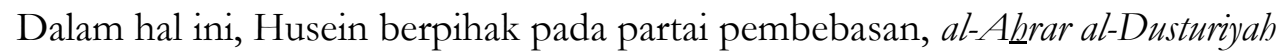
yang cendrung menawarkan pemikiran liberal. Pilihanya didasari oleh argumen bahwa partai ini bertujuan untuk: perbaikan intelektual, kebebasan berfikir, dan menghilangkan perbedaan antara rasio orang timur dengan barat, sehingga Mesir menjadi bagian dari sikap mental Barat, dengan tetap menjaga kepribadiannya. ${ }^{6}$

Ketika kembali ke Mesir, Husein aktif dan menempati posisi strategis dalam bidang kesusastraan dan akademik. Pada tahun 1922 dia menjadi dosen sejarah Yunani dan romawi kuno di Universitas Kairo hingga tahun 1925. Begitu Universitas Kairo beralih status menjadi negeri, Thoha Husien kemudian ditunjuk sebagai dosen sejarah sastra Arab pada Fakulas sastra. Pada saat inilah, dia menulis buku berjudul fi al-Si'ri al-Jabili (1926). Pada tahun 1942-1944 dia diangkat sebagai Rektor Universitas Iskandariyah. Pada tahun 1950-1952 ditunjuk menjadi menteri pendidikan Mesir. Pada tahun 1973, dia mendapat hadiah nobel sastra, dan itu diperolehnya setelah dia meningal dunia pada tahun itu juga, 2 oktober 1973. Dia berumur 84 tahun.

Selain mapan dalam bidang pemikiran Islam tradisional yang dipelajarinya dari ulama' al-Azhar, dan pemikiran modern yang dipelarinya dari para pemikir reformis Mesir, Husein juga mendapat pendidikan modern dari Prancis yang penuh dengan pemikiran rasional. Di sana dia berkenalan dengan pemikiran Rene Descartes yang dikenal sebagai bapak filsuf modern dengan metode keraguannya "saya berfikir maka saya ada".

5 Ibid., hal. 27-28.

$6 \quad$ Ibid., hal. 24 
Metode Descartes ini kemudian dirumuskan menjadi dua prinsip: peneliti hendaknya seorang peneliti melepaskan diri dari pengetahuan sebelumnya, dan dia harus berada dalam keadaan kosong ketika menghadapi obyek penelitiannya. ${ }^{7}$ Sebagai bentuk praktisnya ketika hendak menggunakan metode itu, dia lantas mengosongkan diri dari nasionalismenya dan seluruh identitasnya, mengosongkan diri dari fanatisme keagamaannya dan segala sesuatu yang berkaitan dengannya, dan mengsongkan diri dari segala sesuatu yang berlawanan dengan nasionalisme dan agamanya. Serentak dengan itu, dia menyatakan tidak terikat oleh apapun kecuali pada penelitian yang bersifat ilmiah yang benar. Kendati tidak sampai pada keyakinan, langkah ini menurut dia minimal menghasilkan tarjih. ${ }^{8}$ Ini tentu berbeda dengan pemikir klasik, yang acapkali bersikap fanatik terhadap keAraban dan agamanya.

Ada tiga unsur penting pemikiran Thaha Husein dalam bukunya Fi AlSyi'ri Al-Jahili, pertama, tentang otentisitas syi'ir Jahiliyah, kedua, urgensi pengguanaan "syi'ir Jahiliyah "10 dalam menafsiri al-Qur'an, dan ketiga, pandangan Al-Qur'an tentang masyarakat Jahiliyah. Ketiga persoalan ini akan dibahas secara urut.

\section{Pandangan Otentisitas Syi'ir Jahiliyah}

Thoha Husein mengawali karyanya, fi al-Syi'ri al-Jabili, dengan membedakan dua hal: menerima pendapat para pemikir sebelumnya tentang syi'ir Jahiliyah tanpa kritik, atau menempatkan pemikiran mereka sebagai obyek bahasan kritik. Jika yang pertama berkaitan dengan keimanan yang tenang dan memuaskan, yang kedua berkaitan dengan keraguan dan kegelisahan. Husein memilih yang kedua dengan menempatkan pemikiran klasik sebagai obyek keraguan $^{11}$ dan hanya akan menerima informasi pemikiran mereka jika telah lulus uji ilmiyah. Atas dasar keraguan dan tesisnya itu, dia lantas mulai membahas,

\footnotetext{
Thoha Husein, fi al-Syi'ri al-Jabili..., hal. 74

8 Ibid., hal. 66

$9 \quad$ Ibid., hal. 75-77

10 Ungkapan "syi'ir Jahiliyah" diberi tanda petik “..." karena apa yang disebut syi'ir jahiliyah oleh Husien masih diragukan kebenarannya. Jadi tanda petik dimaksudkan untuk menunda penilaian akan otentisitas apa yang disebut syi'ir jahiliyah.

11 Thoha Husein, fi al-Syi'ri al-Jabili..., hal. 70.
} 
berfikir, dan meneliti otentisitas syi'ir tersebut ${ }^{12}$ dengan menggunakan metode keraguan $^{13}$ yang dipinjamnya dari Descartes.

Menurut dia apa yang selama ini disebut syi'ir Jahiliyah adalah buatan para plagiator di masa Islam. ${ }^{14}$ Kendati syi'ir Jahiliyah yang dekat dengan kehadiran Islam diyakini ada, itupun hanya sedikit sekali dan itu tidak menunjukkan sesuatu apapun tentang masyarakat Jahiliyah. ${ }^{15}$ Dan untuk mengetahui syi'ir yang terakhir ini, menurut dia, sejatinya kita merujuk pada al-Qur'an, sejarah, dan legenda (asatir), bukan melalui syi'ir Jahiliyah itu sendiri. ${ }^{16}$

Untuk membuktikan tesisnya, Husein melihatnya dari dua segi: relasi syi'ir dengan bahasa; dan relasi syi'ir dengan labjah. Sekaligus akan ditunjukkan beberapa motivasi plagiasi yang membuat syi'ir Jahiliyah itu dalam perspektif Husein menjadi tidak otentiks.

\section{Relasi Syi'ir dengan Bahasa}

Pengertian bahasa Arab yang dimaksud Husein dalam hal ini adalah maknanya yang teliti (daqiq) yang terbatas dan yang terdapat di dalam kamus-kamus yang membahas makna lafadznya. Dalam arti lafadz-lafadz yang menunjuk pada maknanya, yang terkadang digunakan dalam arti hakikinya dan terkadang makna majazinya, dan yang mengalami perkembangan yang sesuai dengan tuntutan kehidupan dimana para pemilik bahasa itu hidup. ${ }^{17}$

Setelah melakukan uji ilmiyah, dia kemudian membuat tesis bahwa apa yang disebut syi'ir Jahiliyah ternyata tidaklah mencerminkan bahasa Arab Jahiliyah yang semasa dengan syi'ir Jahiliyah yang diasumsikan para perawi. Untuk membuktikan tesisnya itu, Husein merujuk langsung pada para perawi syi'ir Jahiliyah yang selama ini dijadikan pegangan para pemikir yang meyakini otentisitas syi'ir Jahiliyah.

12 Ibid.

13 Dalam studi epistemologi dikenal adanya dua keraguan: keraguana mutlak dan keraguan metodologis. Yang pertama meragukan adanya kebenaran sama sekali, yang kedua meyakini adanya kebenaran namun meragukan pelbagai metode mencari kebenaran. Karena itu, perdebatannya berkisar pada kemungkinan akal dan indera mengetahui. Keraguan ini berarti menjadi sarana, bukan tujuan. Di antara yang masuk kedalam kategori kedua adalah Al-Ghazali dan Descartes. Rajih Abdul Hamid al-Kurdi, Nadlariatual al-Makrifah: baina Al-Qur'an wa al-Falsafah, (Riyad: Maktabah al-Muayyad, 1992), hal. 104-105; Wail Ghali, "Descartes al-Ghaib an Thaha Husein”, dalam Rasa”il Thoha Husein, (al-Qa”hirah: tp. 1996), hal.102-105; Rene Descartes, Risalab Tentang Metode, hal. 30.

14 Thoha Husein, fi al-Syi'ri al-Jabili..., hal. 71.

15 Ibid., hal. 71.

16 Ibid.

17 Ibid., hal. 87. 
Menurut Husein, para perawi yang meyakini otentisitas syi'ir Jahiliyah membagi Arab menjadi dua bagian: ${ }^{18}$ Arab utara yang bertempat di Yaman, yakni suku Arab Qahtoniyah yang sejak kelahirannya memang murni Arab dan menggunakan bahasa Arab; dan Arab selatan yang bertempat di Hijaz dan merupakan keturunan Ismail. Arab ini disebut Adnaniyah yang sejak awal menggunakan bahasa Ibrani dan Kildaniyah. Akan tetapi, Arab kedua ini mempelajari bahasa Arab dan kemudian menjadikaan bahasa Arab sebagai bahasa alamiah mereka, dan pada saat yang sama melupakan dua bahasa awal yang digunakannya. Jika Arab pertama disebut Arab Aribah, ${ }^{19}$ Arab kedua disebut Musta'ribah.

Di sisi lain, tegas Husein, para perawi itu juga melihat adanya perbedaan substansial antara bahasa Arab kedua masyarakat Arab itu. Perbedaan itu diriwayatkan dari Abu Amr bin al-Ala'. Dia mengatakan "Lisan Hamir (Arab Aribah) bukan lisan kami, dan bahasa mereka bukan bahasa kami (Musta'ribah)". Dua pernyataan ini terkesan kontradiktif. Masyarakat Arab yang awalnya berbeda kemudian menyatu dalam bahasa, namun keberadaan bahasa yang digunakannya ternyata masih berbeda.

Terhadap pernyataan yang kontradiktif ini, Husein kemudian mengajukan pertanyaan ingkari, jika anak keturunan Isma'il yang disebut Arab Adnaniyahmusta'ribah telah mempelajari bahasa Arab Qahthoaniyah-Aribah dan menjadikannya sebagai bahasa resminya, kenapa bahasa Arab musta'ribahAdnaniyah jauh berbeda dengan bahasa Arab aribah-Qahtoniyah, sehingga Abu Amr bin al-Ala' menilai adanya perbedaan bahasa antara keduanya? ${ }^{20}$ Dengan pertanyaan ingkari ini, Husein sebenarnya hendak menegaskan bahwa sejatinya bahasa kedua suku yang sudah resmi menggunakan bahasa Arab itu sama. Namun karena ternyata tidak sama, Husein menyimpulkan bahwa itu artinya ada hal yang perlu dipertanyakan dalam konteks itu.

Pertanyaan filologis-historis dan kritis ini serentak dibarengi dengan keraguannya atas keberadaan Ismail dalam konteks sejarah, yang dianggap sebagai cikap bakal lahirnya Arab musta'ribah-Adnaniyah. Menurut Husein, kendati al-

18 Ibid., hal. 87-88.

19 Arab Aribah terdiri dari 10 faksi: Ad, Tsamud, Thasam, Jadis, Amaliq, Abil, Amim, Wabar, Jasim, dan Qahtan. Mereka dikatakan arab artinya mereka adalah arab yanag benar-benar membumi kearabannya atau pelaku dan pioneer kearaban. Mereka juga terkadang disebut Ba'idah artinya yang telah punah. Sayyid Mahmud al-Qimni, Nabi Ibrabim: Titik Temu-titik Tengkar Agama-agama, terj. Kamran As'ad Irsyadi, (Yogyakarta: LKiS, 2004), hal. 84-85.

20 Thoha Husein, fi al-Syi'ri al-Jabili..., hal. 88. 
Qur'an, Taurat dan Injil memberitakan kisah hijrahnya Ismail ke Arab dan kemudian melahirkan Arab musta'ribah tidak dengan sendirinya membuktikan keberadaannya dalam kenyataan sejarah. Husein menilai kisah itu hanyalah kisah fiksi yang bertujuan untuk membuktikan adanya hubungan antara etnis Arab dengan Yahudi, antara Al-Qur'an dengan Taurat dan Injil bahwa agama-agama itu berasal dari satu Tuhan dan sama-sama membawa pesan tauhit. ${ }^{21}$

Awalnya, hubungan ini menurut Husein bersifat maknawi dan rasional sehingga dibutuhkan penegasan adanya hubungan lain yang bersifat material agar hubungan itu benar-benar terlihat nyata. Kisah Ismail menurut dia adalah salah satu bentuk hubungan yang bersifat material. Al-kisah, masyarakat Arab Quraisy pada awal abad ke VII telah mengalami kemajuan di bidang politik dan ekonomi. Hal ini menurut dia disebabkan oleh perdagangan dan agama. Pada masa ini, Quraisy mengalami kemajuan yang bersifata material dalam bidang perdagangan kemajuan dalam bidang agama dengaan bentuk penyembahan berhala.dan Karena kondisi perdagangan dan Ka'bah pada abad VII M. menjadi tempat masyarakat menjalankan ibadah haji, maka Arab Quraisy menerima kisah tersebut. Di sinilah nilai kisah di atas, kisah kekerabatan antara Arab Qahtoniyah, Adnaniyah dan Yahudi. ${ }^{22}$

Sejalan dengan itu, Husein kemudian masuk lebih jauh pada persoalan bahasa dan syi'ir itu sendiri. Di antara para penyair yang dipandang para perawi menelorkan syi'ir, tegas Husein, terdapat penyair yang dinisbatkan dan berasal dari Arab YamanQahthaniyah-al-Aribah yang berbicara dengan bahasa selain bahasa al-Qur'an. Itu juga dutegaskan oleh Abu Amr al-Ala' bahwa: bahasanya berbeda dengan bahasa Arab", dan juga sebagaimana ditunjukkan penelitian modern bahwa "bahasa mereka bukanlah bahasa Arab".

Bahkan Husein menemukana hal lain yang cukup mengagetkan. Ketika membaca syi'ir-syi'ir yang dinisbatkan kepada Arab Yaman-Qahthiniyah Aribah di masa Jahiliyah itu, ternyata, dia sama sekali tidak menemukan adanya perbedaan substansial antara syi'ir mereka dengan syi'ir yang berasal dari Arab AdnaniyahMusta'ribah. Tidak hanya sebatas itu, Husein juga tidak menemukan perbedaan yang substansal antara bahasa syi'ir yang diasumsikan milik para penyair itu dengan bahasa Al-Qur'an. ${ }^{23}$

21 Ibid., hal. 89.

22 Ibid., hal. 89-90.

23 Ibid., hal. 92. 
Ini menunjukan bahwa apa yang disebut syi'ir Jahiliyah yang dinisbatkan kepada Arab Qahthaniyah-Aribah dalam pandangan Husein tidaklah benar-benar buatan para penyair mereka.

\section{Relasi Syi'ir Jahiliyah dengan Lahjah}

Selain bukti bahasa, bukti ketidakotentikan syi'ir Jahiliyah juga ditunjukkan oleh dialek (labjab) yang digunakannya. Menurut para perawi syi'ir Jahiliyah, bahasa Arab Adnan sebelum kehadiran Islam tidak satu jenis, melainkan berbeda-beda, begitu juga lahjahnya, karena mereka terdiri dari beberapa Qabilah. Perbedaan qobilah tentu mempengaruhi bahasa dan lahjahnya.

Berbeda dengan hasil kesimpulan para perawi, Husein justru menemukan sebaliknya. Lahjah bahasa syi'ir Arab Jahiliyah menurut dia ternyata tidak jauh berbeda satu sama lain, antara mutawwalat atau muallaqat karya Amr al-Qais dari Kindah atau Qahton; karya Zuhair, Antarah, dan Labid dari Qais; dan qasidah karya Turafah, karya Amr Bin Kalsum, dan karya Haris bin Hillazah yang berasal dari Rabi'ah. Ketujuh muallaqat dan qasidab yang dijadikan contoh otentisitas syi'ir Arab Jahiliyah ini menurut Husein tidak menunjukkan adanya perbedaan sama sekali, baik dari segi bahasa maupun lahjahnya, padahal mereka berasal dari qabilah yang berbeda-beda. Ini seolah membuktikan bahwa perbedaan qabilah tidak mempengaruhi bahasa dan lahjah para penyair dalam menggubah syi'irnya. ${ }^{24}$

Atas dasar itu, Husein kemudian membedakan dua hal: mempercayai bahwa tidak ada perbedaan dari segi bahasa dan lahjah antara qabilah Adnan dan Qahton; atau meyakini bahwa karya-karya yang disebut syi'ir Arab Jahiliyah itu bukan buatan para penyair Arab Jahiliyah dari qabilah-qabilah itu, melainkan dibuat setelah kehadiran Islam? Karena para perawi meyakini bahwa bahasa yang digunakan Arab Qahtoniyah dan Adnan berbeda, baik dari segi bahasa maupun lahjahnya, maka Husien memilih hal kedua. ${ }^{25}$ Menurut dia, hal itu membuktikan bahwa syi'ir itu dibuat bukan oleh penyair Jahiliyah.

Dengan demikian bisa dipahami bahwa selain melalui bahasa, indikasi ketidakotentikan syi'ir Jahiliyah juga bisa ditunjukkan oleh lahjah yang digunakan para penyair dalam menulis syi'irnya. Syi'ir itu dibuat oleh para plagiator di era kehadiran Islam.

\footnotetext{
${ }^{24}$ Ibid., hal. 95-96.

${ }^{25}$ Ibid., hal. 96.
} 


\section{Beberapa Sebab Munculnya Plagiasi Syi'ir Jahiliyah}

Thoha Husein menyebutkan lima hal yang menjadi penyebab munculnya plagiasi dan jastifikasi atas syiì Jahiliyah. Kelima unsur itu secara prinsipil dimaksudkan untuk membuktikan adanya kaitan Islam dengan realitas pra-Islam yang disebut masyarakat Jahiliyah. Sebab, menurut Husein, merupakan kebiasaan plagiator menggunakan syiir untuk membuktikan adanya kaitan tersebut. Kelima unsur tersebut adalah:

\section{a. Politik}

Thoha Husein melihat penyebab lahirnya plagiasi di bidang politik dari sudut pergumulan nabi Muhammad dan para sahabatnya dengan kaum Quraisy. Hal ini bermula dari sejarah hidup dan dakwah Muhammad sebagai pembawa ajaran baru di dunia Arab yang sama sekali berbeda dengan ajaran yang dianut masyarakat Arab pada saat itu. Sebagai ajaran baru, perlawanan dari penganut ajaran lama tidak bisa dihindari. Selain perlawanan dalam bentuk fisik, Muhammad juga menghadapi perlawanan lisan dalam bentuk debat. Itu terlihat dari perintah Al-Qur'an kepada Muhammad agar menyampaikan dakwahnya dengan cara bijaksana, nasehat yang baik, dan mendebat mereka dengan cara yang paling baik. Ini terutama dilakukan karena pada saat itu Muhammad beserta pengikutnya masih berada dalam keadaan lemah. Pergumulan Muhammad dengan kaum Quraisy selama di Makkah menurut Husein mengambil bentuk "pergumulan keagamaan". ${ }^{26}$

Setelah mengadakan perjanjian Aqabah tahun $622 \mathrm{M}$ dengan utusan dari suku Khuzraj dan Aws dari Madinah, Muhammad kemudian mendorong umatnya untuk hijrah ke Madinah. Masalah pertama yang dipandang mendesak oleh Muhammad selain persoalan internal kaum Muhâjirîn dengan kaum Anshâr, adalah problem kaum Yahudi, lebih-lebih secara ekonomis mereka lebih mendominasi ketimbang kedua suku lainnya. Dengan kekuasaannya di bidang ekonomi, jelas mereka tidak menyukai kedatangan Muhammad, apalagi Muhammad yang semula hendak dimanfaatkan kaum Yahudi sebagai senjata untuk membalas dendam terhadap kedua suku tersebut ternyata telah terlebih dahulu dipegang oleh keduanya. Di samping itu, kaum Yahudi mempunyai hubungan yang rapat dengan kaum Quraisy Makkah dan orang-orang mereka tersebar luas di beberapa daerah yang penduduknya memusuhi Islam. ${ }^{27}$

26 Ibid., hal. 113.

27 Seed Ameer Ali, Api Islam, terj. H.B. Yassin, (Jakarta: PT Bulan Bintang, 1978), hal. 167. 
Setelah itu, Muhammad mengadakan perjanjian damai untuk mengatur kehidupan antara komunitas yang berada di Madinah, khususnya kaum Yahudi yang mempunyai posisi kuat secara ekonomi dan politik di Madinah. Perjanjian tersebut melukiskan sebuah deklarasi mengenai hubungan antara Ummah yang kemudian dikenal dengan Piagam Madinah. ${ }^{28}$ Di dalamnya dirumuskan dengan jelas hak-hak dan kewajiban orang Islam yang mengikat kalangan mereka sendiri dan hak-hak dan kewajiban orang-orang Islam dengan Yahudi. ${ }^{29}$

Namun, justru bersamaan dengan itu pula, permusuhan Muhammad dengan suku Quraisy menurut Husein akhirnya semakin melebar. Tidak sebatas menyangkut apakah Islam sebagai agama yang benar atau tidak. Jika semasa di Makkah mengambil bentuk permusuhan keagamaan, antara agama baru yang dibawa Muhammad dengan agama berhala yang dianut masyarakat Arab Quraisy, permusuhan melebar pada ranah yang lebih luas, yakni dalam bentuk politik dan ekonomi, ${ }^{30}$ antara masyaraat Makkah yang diwakili Quraisy dengan masyarakat Madinah yang diwakili Umat Islam dan beberapa kelompok yang ada di Madinah, antara Quraisy dan Anshor. Padahal menurut Husein, sebelum hijrahnya Nabi, hubungan Quraisy dengan suku Aus dan Khazaj sangat erat, karena kedua suku itu menjadi jalan perdagangan suku Quraisy menuju ke Syam.

Kisah pergumulan itu tentunya tidak dimaksudkan sebaga informasi sejarah belaka. Husein melihat lebih jauh lagi. Menurut dia, pergumulan keagamaan, politik dan ekonomi pada gilirannya melibatkan pedang dan syi'ir. Untuk menjastifikasi kemenangan Islam dalam perang badar dan kemenangan Quraisy dalam perang uhud, masing-masing menjastifikasi kelompoknya dengan menggunakan syi'ir. Sementara orang-orang Quraisy Makkah menjastifikasi diri sebagai suku Quraisy yang terhormat dan kuat terbukti dengan kemenangannya dalam perang Uhud, orang-orang Madinah tentu tidak kalah saing. Mereka juga mengeluarkan syi'ir untuk menjastifikasi kelompoknya dan menunjukan kemenangannya dalam perang badar. Melalui syi'ir mereka menghina kelompok lawannya, mendebat mereka dan bahkan

28 Ruslani, Masyarakat dan al-Kitab dan Dialog Antar Agama, Study atas Pemikiran Muhammad Arkoun (Yogyakarta: Yayasan Bentang Budaya, bekerjasama dengan yayasan Adikarya IKAPI dan The Ford Foundation, 2000), 113.

29 Seed Ameer Ali, Api Islam..., hal. 167.

30 Thoha Husein, fi al-Syi'ri al-Jabili..., hal. 114-115. 
menuduh sesat mereka. Karena itu, Husein berkesimpulan bahwa fanatisme politik menjadi penyebab munculnya plagiasi syi'ir yang kemudian dinisbatkan kepada masyarakat Jahiliyah. ${ }^{31}$

\section{b. Agama}

Plagiasi syi'ir Jahiliyah juga disebabkan oleh fanatisme keagamaan. Bahkan menurut Husein, faktor ini lebih dominan daripada faktor politik. Plagiasi yang disebabkan faktor keagamaan ini tidak saja terjadi pada masa Umayyah, tetapi juga meluas ke masa pemerintahan khalafah al-Rasidin. Ada beberapa faktor munculnya plagiasi syi'ir Jahiliyah yang berkaitan dengan agama.

Pertama, kepentingan untuk "menjustifikasi kabsahan Muhammad sebagai Nabi" dan itu terutama ditujukan "untuk memuaskan kalangan masyarakat umum", bahwa Muhammad dari Arab Quraisy memang “ditunggu-tunggu” kehadirannya, bukan hanya oleh para rahib Yahudi dan pendeta Kristen, tetapi juga oleh Jin. ${ }^{32}$ Syi'ir Jin menurut mereka bahkan lebih hebat daripada syi'ir manusia, bahkan dalam hal tertentu, syi'ir para penyair mendapat ilham dari Jin. Tujuan plagiasi ini tentu dimaksudkan untuk memuaskan kebutuhan masyarakaat awam yang menghendaki setiap sesuatua sebaga mukjizat dan bahwa salah satu kebenaran kenabian Muhammad adalah bahwa dia selalu ditunggu-tunggu kehadirannya. ${ }^{33}$

Kedua, "upaya mengukuhkan superiorias Nabi melalui keluarganya dan nasabnya dari Quraisy “. 34 Menurut Husein, masyarakat akan merasa puas jika Muhammad murni dan sebagai pilihan dari keluarga besar Bani Hasyim, Banu Hasim merupakan pilihan dari keluarga besar Bani Manaf, Bani Manaf merupakan pilihan dari keluarga besar Kussai, Kussai merupakan pilihan dari keluarga besar Quraisy, Quraisy merupakan pilihan dari keluarga Mudir, Mudir merupakan pilihana dari keluarga besar Adnan, Adnan merupakan pilihan dari keluarga besar Arab, dan Arab merupakan pilihan sempurna umat manusia. Menurut Husein, merupakan karakter kisah Arab mengikutsertakan syi'ir dalam kisah terutama jika yang menjadi sasarannya adalah untuk memuaskan masyarakat umum.

31 Ibid., hal. 133.

32 Ibid., hal. 134-137.

33 Ibid., hal. 137.

34 Ibid., hal. 138. 
Jadi, mereka menisbatkan keluarga Muhammad dengan Abdullah, Abdul Muthallib, Hasyim, Abdi Manaf dan Kusai sebagai suku yang menduduki posisi terhormat di kalangan mereka bahkan di dunia Arab pada umumnya. Kisah selanjutnya, tentu pergumulan di antara suku-suku Arab itu akan memperrebutkan tiket keluarga Nabi, terutama antara bani Umayyah dengan bani Hasyim pasca Nabi. Kelompok umayyah akan melegitimasi diri dengan kisah kejayaan Umayyah, begitu juga dengan bani Hasyim. Dan hal itu bisa dilakukan dengan syi'ir.

Ketiga, penggunaan syi'ir untuk menakwil kisah-kisah Al-Qur'an tentang umat terdahulu, seperti kaum Ad dan Tsamud. Menurut Husen, para perawi syi'ir itu menisbatkan banyak syi'ir kepada kaum itu, bahkan kepada bani Adam, misalnya kisah permusuhan antara Qabil dan habil. Menurut husein, para perawi banayak mengaitkan syi'ir kepada mereka. ${ }^{35}$

Keempat, adanya keinginan umat Islam untuk mempelajari al-Quran dari segi kebahasaannya dan menetapkan kebenaran lafadz-lafadz dan maknanya. Mereka merasa perlu menegaskan bahwa Al-Qur'an adalah kitab berbahasa Arab dan lafadz-lafadznya sesuai dengan bahasa Arab. Karena itu, mereka kemudian hendak mengukur keAraban Al-Qur'an dengan syi'ir Arab dengan harapan tidak lagi muncul keraguan akan keAraban al-Qur'an. ${ }^{36}$ Husein mengkritik hal ini dan menegaskan bahwa nash Arab yang tidak lagi mengandung keraguan sehingga ia menjadi sumber paling terpercaya bagi keaslian bahasa Arab adalah Al-Qur'an itu sendiri. Justru melalui Al-Qur'an itulah, kita mengukur kemurnian syi'ir Arab Jahiliyah, bukan sebaliknya. ${ }^{37}$

Kelima, keinginan untuk membuktikan otentisitas Islam sebagai agama yang mempunyai hubungan dengan agama sebelumnya yang dianut masyarakat Arab. Mereka hendak membuktikan bahwa agama Islam yang dibawa Muhammad merupakan pelanjut dan penyempurna agama-agama yang diturunkan kepada para nabi sebelumnya. Agama yang dimaksud diceritakan oleh Al-Qur'an. Selain Nabi-Nabi dan agama yang tidak diceritakan, Al-Qur'an menceritakan pada kita tentang kitab injil dan taurat, juga menyebut dan mendebat agama pemilik kedua kitab tersebut yakni Yahudi dan Nasrani. AlQur'an juga menyebut kitab lain, yakni subuf Ibrahim sebagai kitab millah

35 Ibid., hal.141-142.

36 Ibid., hal. 142.

37 Ibid. 
ibrahim. Millah ibrahim ini selama ini disebut hanafiyah yang menurut Husein belum ditemukan definisi yang pas bagi kata itu.

Penilaian pun berlanjut. Jika terhadap kedua agama sebelumnya ada tuduhan telah terjadi perubahan, tidak demikian halnya dengan agama terakhir. Tak seorangpun yang mengingkari millah Ibrahim. Selain sebagai agama paling awal, ia juga tidak pernah mengalami perubahan sebagaimana Nasrani dan Yahudi. ${ }^{38}$ Karena itu, mereka meyakini agama ibrahim merupakan agama masyarakat Arab, namun kemudian terjadi penyimpangan dengan menyembah berhala. Hanya sedikit penganut agama ini yang tetap dengan agamanya, yang kemudian dikenal sebagai pengikut agama Ibrahim. Agama Hanafiyah atau millah Ibrahim inilah yang kemudian dianggap sebagai cikal bakal lahirnya agama Islam yang dibawa Muhammad. Bahkan Al-Qur'an sendiri menyebutkan agar Muhammad mengikuti millah Ibrahim. Terhadap agama ibrahim inilah umat Islam mengikatkan diri sehingga muncul pemikiran di kalangan mereka bahwa Islam merupakan pembaharu agama ibrahim yang selama ini telah disimpangkan oleh masyarakat Arab.

\section{c. Qisah}

Kisah menurut Husein bukanlah bagian dari agama dan bukan pula bagian dari politik, namun, ia mempunyai hubungan erat dengan agama dan politik. Sebaliknya, kisah adalah bagian dari sastra Arab yang bertitik tolak pada khayal. Namun penting dicatat bahwa, kendati berkaitan dengan sastra, kisah $^{39}$ Arab tidak bernilai sastra sama sekali. Agar bernilai sastra, kisah membutuhkan syi'ir ${ }^{40}$ Husein mencontohkan kisah "al-fu laylatin” dan kisah Antarah. Ini berbeda dengan kisah Yunani yang sejak awal memang sarat dengan nilai sastranya. ${ }^{41}$ Karena itu, tegas Husein, para pengisah di era Umayah dan Abbasiyah membutuhkan hiasan sastra agar kisahnya diterima sebagai bagian dari karya sastra yang layak dikonsumsi. Oleh karena syi'ir menjadi bagian dari kebanggaan sastrawi masyarakat Arab pra islam, para pengisah ${ }^{42}$ acapkali memasukkan unsur syi'ir ke dalam kisah agar ia mempunyai nilai, baik nilai estetika, politik maupun untuk meumbuhkan fanatisme kebangsaan.

\footnotetext{
38 Ibid., hal. 145-146.

39 Ibid., hal. 159-160.

40 Ibid., hal.161.

41 Ibid., hal. 157.

42 Ibid., hal.161-164.
} 
Keberadaan sastra, termasuk sastra kisah tidak dipelajari di awal kehadiran Islam. Ia dipelajari di era kehadiran islam, dengan berbagai tujuan, seperti politik, fanatisme kebangsaan maupun estetika. Dengan tujuan-tujuan itu semua, sastra kisah subur di kalangan masyarakat Arab. Jika kita mempelajari biografi para pengisah secara mendalam yang terbiasa berkisah di masjid-masjid Bashrah, Makkah, Madinah dan tempat lainnya akan ditemukan bukti-bukti adanya hubungan mereka dengan partai politik, di samping agama. ${ }^{43}$ Husein mencontohkan pengisah Ibnu Ishaq yang berkecendrungan pada bani Hasyim, sehingga dia menduduki jabatan penting dalam kepemimpinan Abbasiyah. ${ }^{44}$

Selain itu, kisah juga digunakan untuk membaca simbol yang masih samar. Jika sastra secara umum dijadikan sebagai sarana menafsiri, menakwil serta mengistimbat hukum dari Al-Qur'an dan al-Hadits sebagai sumber asasi Islam, ${ }^{45}$ sastra kisah digunakan untuk menafsiri simbol-simbol, mitos-mitos, kata-kata asing agar pendengar merasa nikmat mendengarnya. ${ }^{46}$ Dari sini bisa dipahami bahwa syiìr yang dihiaskan pada kisah itu hanya sekedar diposisikan sebagai alat menafsir, atau memperjelas nama-nama, atau mensyarahi tamtsil yangada di dalamnya. Dengan sendirinya, pelbagai kisah tentang kaum Ad, Tsamut, Thasm, Jadis, Jurhum dan Amaliq, tegas Husein tidak mempunyai dasar sama sekali dalam kenyataan sejarah. ${ }^{47}$

\section{d. Fanatisme Kebangsaan}

Dari segi bahasa, syu'ubiyah berasal dari kata al-syu'ub: jama' dari sya'bun, yakni generasi segolongan manusia. Ia lebih luas dan menyeluruh maknanya dari qabilah, yang biassanya dikenal di dunia Arab. Kata ini biasanya meliputi bangsa seperti Arab adalah sya'bun, Persia adalah Sya'bun, dan Romawi adalah Sya'bun. Sebagian orang berpendapat, kata itu diambil dari ayat Al-Qur'an yâ ayyuha al-Nâs innâ khalaqnâkum min dzakarin wa untsâ, waja'alnâkum syu'úban wa qabâila li ta'ârafu. Namun menurut Ahmad Amin, kata ini tidak diambil secara harfiyah dari ayat Al-Qur'an di atas. Sebab, ia baru muncul di era Abbasiyah awal. ${ }^{48}$ Pada pertengahan abad pertama hijriyah, orang-orang

43 Ibid., hal. 159.

44 Ibid., hal. 158-159.

45 Ibid., hal. 158.

46 Ibid., hal.166.

47 Ibid., hal. 171.

48 Ahmad Amin, Duha al-Islam, (al-Qahirah: Maktabah al-Usrah, al-Hay'ah al-Mishriyyah alAmah li al-Kitab, dan al-A'Mal al-Diniyah, 2002), hal.71-72. 
Persia yang telah ditaklukkan dan menjadi tawanan bahkan budak orang-orang Arab, mulai bergabung dengan orang-orang Arab. Mereka menjadi orang Arab, mengakui kearaban dirinya, menempati beberapa daerah khusus di dunia Arab, di sana mereka beranak pinak, dan berbicara menggunakan bahasa Arab sebagaimana orang Arab sendiri. Tidak hanya sebatas itu, mereka juga mulai terlibat dalam pergumulan kebangsaan dan politik dengan masyarakat Arab, baik dalam bentuk terjun langsung ke dalam partai-partai politik atau melalui syi'ir yang disumbangkan penyair-penyair mereka pada parta-partai politik sebagai pemompa semangat dan fanatisme. ${ }^{49}$

Namun fanatisme kabangsaan (syu'ubiyah) memaksa mereka tidak fair dalam bergaul dengan masyarakat Arab. Mereka hendak membalas dendam terhadap bangsa Arab yang telah mengalahkannya dengan berbagai cara, baik melalui agama, politik maupun sastra, termasuk di antaranya melalui syi'ir. Karena itu, Thoha Husien menyebut orang-orang Persia yang pernah ditaklukkan Arab menjadi dalang plagiasi syi'ir Arab Jahiliyah yang berkaitan dengan motivasi fanatisme keangsaan. Mereka mulai menyusun syi'ir sebagaimana syi'ir para penyair Arab.

Keterlibatan mereka dalam partai politik Arab membuat mereka mudah diterima di kalangan orang-orang Arab yang tentunya membutuhkan dukungan politik, bahkan syi'ir, baik sebagai legitimasi dan pemompa semangat dan fanatisme maupun sebagai alat kritik. Bentuk syi'ir mereka karenanya pasti sesuai pesanan, mengikuti warna politik di mana mereka terlibat. Jika partai politik tertentu menginginkan mereka membuat syi'ir yang menyudutkan, menyerang dan mencela partai politik lain, mereka akan membuat syi'ir sesuai pesanannya. Dan tentu, syi'ir yang mereka buat selalu mengaitkan partai politik tertentu dengan para pendahulu mereka, yang telah terbiasa dengan sikap membangga-banggakan leluhurnya, misalnya syi'ir yang digunakan untuk mendukung partai Umayah, syi'irnya pasti dikaitkan dengan para pendahulu Umayyah, begitu juga syi'ir yang dibuat untuk partai yang berafiliasi kepada Abbasiyah juga dikaitkan dengan pendahulunya, begitulah seterusnya. Bahkan tidak jarang mereka saling mengkaitkan diri dengan Quriasy dan keluarga Nabi Muhammad misalnya untuk mendapatkan dukungan politik. 
Disadari atau tidak, hal ini pada gilirannya membuat kacau partai-partai politik Arab, dan pada saat yang sama, membuat mereka (orang-orag Persia) mendapat legitimasi bagi mereka sendiri untuk mencela orang-orang Arab dan membangga-banggakan diri sebagai orang-orang mulya sebagaimana keadaan mereka sebelum ditaklukan orang-orang Arab. ${ }^{50}$ Tidak jarang mereka membuat syi'ir yang mengunggulkan orang-orang Persia. Sikap penyair Persia yang demikian tentu membuat tidak adanya keikhlasaan pada mereka. Yang ada hanyalah bagaimana mereka eksis sebagaimana layaknya orang Arab, bebas dari perbudakan sebagai tawanan, dan bahkan juga untuk membalas dendam atas orang-orang Arab yang telah mengalahkan mereka. ${ }^{51}$

Dari kenyataan di atas, bisa dilihat, tegas Husein, bagaimana fanatisme kebangsaan penyair Persia mendorong mereka untuk memplagiasi syi'ir pra Islam. Al-Jahid pun yang konon murni membuat syi'ir demi kepentingan keilmuan dan mencoba menghilangkan fanatisme kebangsaan yang membabi buta dalam syi'ir, tegas Husein, masih tidak bisa melepaskan fanatismenya sendiri. Sehingga karyanya Kitab al-Ashâ dan albelum bisa diyakini sebagai karya yanag benar-benar kosong dari fanatisme kebangsaan. ${ }^{52}$

\section{e. Kepentingan Perawi}

Selesai membicarakan beberapa motivasi plagiasi syi'ir Jahiliyah di atas, kini masuk pada poin kelima yang menurut Husein tidak kalah besar pengaruhnya dalam plagiasi syi'ir Jahiliyah ke dalam islam. Yakni para perawi yang menukil sastra Arab Jahiliyah kepada kita dan sekaligus membukukannya. Husen membagi mereka menjadi dua golongan: para perawi yang berasal dari Arab yang membawa pengaruh kerabaannya, dan perawi yang berasal dari orang-orang taklukan dari Persia (al-mawali) yang tentunya membawa pengaruh Persia. Selain itu, mereka juga masih terpengaruh oleh beberapa hal lainnya, misalnya sikap tidak serius, sikap berlebihan-lebihan, dan bahkan mereka menghindari dasar-dasar agama dan akhlak. Justru mereka berpaling pada persoalan-persoalan yang tidak mendapat keabsahan agama dan akhlak. ${ }^{53}$

50 Ibid., hal. 176.

51 Ibid., hal.174.

52 Ibid., hal. 180-183

53 Ibid, hal. 184-185 
Sebagai penjabaran lebih lanjut dari sikap mereka yang tidak serius dan cendrung berlebihan itu ditujukkan Husein dengan cara membagi para perawi itu secara umum yang bisa mewakili seluruh perawi menjadi dua kategori: Hammad al-Rawiyah, dan Khalaf al-Ahmar.

Hammad al-Rawiyah adalah pemimpin golongan Kuffah dalam hal riwayaat dan pemeliharaan, sedang Khalaf al-Ahmar sebagai pemimpin golongan Bashrah. Keduanya menurut Husein sama-sama bersikap berlebihlebihan atas dirinya, membanggakan diri sendiri, tidak memiliki sopan santun, akhlak, dan juga tidak memiliki kewibawaan yang diizinkan agama. Keduanya sebagai pemabuk, fasik, dan acapkali mengikuti kehendak hawa nafsunya, misalnya minum khamer. Demikian lah Husein mendiskripsian kedua perawi yang terkenal itu. ${ }^{54}$

Selanjutnya, Husein merinci kedua perawi itu. Hammad adalah sahabat dari Hamad Ajrad dan Hammad al-Zabarqan dan Muti' bin Iyas. Menurut Husein, mereka semua tidak ada yang berwibawa. Sedang Khalaf adalah sahabat Walibah bin Habab dan menjadi guru Abu Nuwas. Mereka semua bagi masyarakat Iraq dipandang tidak mempunyai wibawa dan acapkali berbuat mesum, menghina agama dan dituduh zindiq. Menurut Husein, umat Islam sepakat tidak memberi nilai kebaikan pada mereka, dan sama sekali tidak memberi nilai sebagai orang yang membawa kebaikan pada agama dan dunia. ${ }^{55}$

Penduduk Kuffah sepakat bahwa guru mereka dalam riwayat adalah Hammad. Darinya mereka mengambil riwayat tentang syi'ir. Sedang penduduk Bashrah sepakat bahwa guru mereka dalam riwayat syi'ir adalah Khalaf. Darinya mereka mengambil syi'ir. Namun kedua penduduk Kufah dan Bashrah sepakat juga bahwa kedua perawi itu acapkali menyangkal ajaran agama, akhlak dan sikap muru'ah. Mereka juga sepakat bahwa keduanya tidak menghafal syi'ir dengan baik, begitu juga tidak baik dalam meriwayatkannya. Mereka juga mengakui bahwa keduanya adalah penyair yang bertaqlid sehingga sulit dibedakan antara syi'ir yang diriwayatkannya dengan syi'ir yang diplagiasinya. ${ }^{56}$

Selain kedua perawi dengan tipikalnya itu, Husien mencatat ada perawi lain yang tidak lebih kecil kebohongan dan plagiasinya, yakni Abu Amer alShaibani. Dia suka mengumplkan syi'ir-syi'ir dari suku-suku kemudian

\footnotetext{
54 Ibid., hal. 185

55 Ibid., hal. 185

56 Ibid., hal. 186
} 
dibukukan ke dalam satu mushaf dan menggantungkannya di Masjid Kufah. Musuh orang ini sempat menilai bahwa riwayatnya sebenarnya bisa dipercaya andaikata dia tidak membiasakan diri meminum minuman khamr. Konon, dia meriwayatkan sebanyak tuju puluh (70) syiir suku (qabilah).$^{57}$

Bahkan tegas Husein tidak jarang riwayat-riwayat itu lahir dari sumber yang suka mengkomersialkan dan juga digunakan oleh para perawi yang suka mengkomersialkan. Ini biasanya dilakukan para perawi yang mencoba mencari informasnya dari orang-orang baduwi yang dianggap masih steril dari campuran. Namun karena kepentingan tertentu, justru orang-orang baduwih itu sendiri berbohong, membuat-buat syi'ir dan bahkan acapkali memperbanyak syi'ir-syi'ir yang asing bagi para perawi itu, dengan tujuan semakin banyak mengelurakan syi'ir maka semakin banyak pula laba yang mereka dapat, seperti abu domdom. ${ }^{58}$

Untuk mendukung analisisnya, Husein menampilkan cerita Ibnu Salam tentang Abi Ubaidah. Bahwa pada suatu ketika, Daud bin Mutammim bin Nuwairah datang ke Bashrah. Kepadanya, Abu Ubaidah bertanya tentang syi'ir ayahnya. Kemudian dia mendapat jawaban sesuai dengan yang diharapkan. Namun begitu Ubaidah selesai dengan kepentingannya, orang baduwi yang nampaknya tidak mau membuat kecewa Ubaidah kemudian meriwayatkan lagi sebuah syi'ir yang sebenarnya tidak pernah dikatakan ayahnya. Ubaidah mengetahui hal itu. ${ }^{59}$

Ketiga perawi syi'ir di atas, yang oleh Husein disebut sebagai perawi yang rusak muru'ahnya, suka berbohong, dan sebagainya, pada gilirannya akan berpengaruh terhadap nilai syi'ir yang diriwayatkannya. Sebagaimana watak perawi yanag rusak, maka riwayat-riwayat syi'irnya pasti juga rusak. Karena itu, Husein kemudian menyarankan untuk menolak syi'ir-syi'ir yang diriwayatkan mereka. ${ }^{60}$

\section{Urgensi Syi'ir Jahiliyah dalam Studi Al-Qur'an}

Alasan penggunaan syi'ir Jahiliyah dalam menafsiri Al-Qur'an didasari pemahaman bahwa syi'ir menjadi cerminan masyarakat dimana penyair menggubah

57 Ibid., hal. 186

58 Ibid., hal. 189-190

59 Ibid., hal. 190.

${ }^{60}$ Ibid., hal. 188. 
syi'irnya. Karena dalam tradisi sastra dikenal adagium bahwa karya sastra, baik berupa prosa maupun puisi suatu bangsa adalah hasil intelektual generasinya dan menggambarkan karakter serta daya hayalnya. ${ }^{61}$

Umat Islam terlanjur mempercayai bahwa masyarakat Arab pra-Islam khususnya mempunyai peradaban syi'ir, sehingga Al-Qur'an pun dipandang turun dalam rangka menandingi syi'ir para penyair Arab pra islam. Daya magic syiì dan kahanah secara esensial dipandang melekat pada al-Qur'an. Kisah-kisah kekuatan syiir dan kahanah ${ }^{62} \mathrm{Al}$-Qur'an acapkali mengisi ruang sejarah perjalanan Al-Qur'an di dunia Arab. Konon terdapat pandangan dan pengaruh beragam tentang kekuatan magic Al-Qur'an di era permulaan al-Qur'an. Umar bin Khattab memandang AlQur'an mempunyai i'jaz, yang melebihi i'jaz syi'ir dan kahanah yang pada gilirannya membuatnya masuk Islam hanya dengan mendengarkan surat Thaha yang dibaca adik dan iparnya. Setelah membacanya, dia mengatakan "alangkah indah dan mulianya kalam ini”. Berbeda dengan pengalaman Umar, al-Walid Ibnu al-Mughirah justru menyarankan kaumnya untuk menutup telinga dari bacaan Al-Qur'an untuk menghindari daya sihir al-Qur'an. Al-Walid berkata “sesungguhnya Al-Qur'an ini adalah sihir yang dipelajari". ${ }^{63}$

Dengan adagium dan kenyataan di atas, wajar jika kemudian ada anggapan bahwa syi'ir Jahiliyah layak digunakan untuk mengetahui istilah-istilah sulit dalam al-Qur'an. Pelbagai tafsir yang berkembang dalam duia Islam, baik tafsir klasik seperti a-Thabari maupun tafsir kontemporer, pasti ditemukana adanya banyak syi'ir di dalamnya.

Namun bersamaan dengan ditemukannya bukti ketidakotentikan apa yang disebut syi'ir Jahiliyah, dan kendati syi'ir Jahiliyah itu diakui adanya, namun ia ternyata tidak sampai secara mutawatir dan soheh kepada masa kita, maka Thoha Husein mengajukan tesis bahwa apa yang disebut syi'ir Jahiliyah itu tidak bisa digunakan untuk menafsiri Al-Qur'an. Selain tidak otentiks, syi'ir-syi'ir itu juga memandang secara subyektif dan tendensius terhadap masyarakat Arab pra-Islam. Mereka dipandang sebagai masyarakat yang paling bobrok peradabannya, bersamaan dengan itu, keberhasilan Islam yang dibawa Muhammad dipandang sebagai bentuk mukjizat yang tak tertandingi oleh agama apapun di dunia.

61 Syahrin Harahap, Al-Qur'an dan Sekularisasi..., hal. 133.

${ }^{62}$ Sayyid Qutub, Keindahan Al-Qur'an yang Menakjubkan: Buku Bantu Memahami Tafsir fi Zhilalil Qur'an, terj. Bahrun Abu Bakar, (Jakarta: Rabbani Press, 2004), hal. 13.

${ }^{63}$ Ibid., hal. 16-17. 
Sebagai gantinya, Husien menawarkan bahwa satu-satunya cara melihat secara obyektif kondisi masyarakat Arab pra-Islam adalah melalui teks yang otentisitasnya tidak diragukan lagi, yakni Al-Qur'an, ${ }^{64}$ syi'ir yang semasa dengan Nabi dan yang pernah mendebat Nabi, atau yang datang sesudahnya dan bahkan syi'ir masa kekuasaan Umayah. ${ }^{65}$

\section{E. Masyarakat Arab Pra-Islam menurut Al-Qur'an}

Istilah masyarakat Jahiliyah selama ini dilabelkan kepada masyarakat Arab pra Islam. Mereka dipahami sebagai masyarakat yang bodoh dalam segala hal. Istilah Jahiliyah pun digeneralisir meliputi seluruh dimensi kehidupan mereka. Hal ini nampaknya tidak disetujuai Husein. Menurut dia, pandangan negatif terhadap masyarakat Jahiliyah lahir karena mereka merujuk pada syi'ir yang tidak otentiks. Istilah ini diberikan pada mereka didasarkan pada logika dialektika untuk menjastifikasi kebenaran Islam sebagai ajaran yang memberi petunjuk dan mencerahkan kepada manusia dan itu berbeda dengan ajaran agama masyarakat Arab pra-Islam.

Jika kita melihat masyarakat Arab pra-Islam dari sudut pandang Al-Qur'an, akan ditemukan suatu gambaran masyarakat yang kuat dalam berkeyakinan dan berargumen. Batapa para penyair yang mendebat Nabi, pasti mereka memahami apa yang disampaikan Nabi. Bagaimana bisa mendebat Nabi jika mereka tidak memahaminya. Terlepas mereka percaya atau tidak, hal itu menunjukkan bahwa mereka bukanlah masyarakat yang bodoh, melainkan masyarakat yang berperadaban.

Al-Qur'an menceritakan tentang keberagamaan masyarakat Arab pra-Islam yang mengajarkan kepada umatnya untuk kuat dalam berkeyakinan dan berargumen, ${ }^{66}$ bahkan dengan Muhammad. Jadi, berbeda dengan pandangan apa yang disebut syi'ir Jahiliyah, Al-Qur'an menurut Husein, menilai betapa masyarakat Arab Quraisy sebagai masyarakat beragama yang kuat imannya. ${ }^{67}$

Al-Qur'an juga menceritakan tentang rasionalitas masyarakat Arab pra Islam, yang tidak ditemukan dalam syi'ir tersebut. Misalnya kemampuannya berdebat. Al-

\footnotetext{
64 Thoha Husein, fi al-Syi'ri al-Jabili..., hal. 79.

65 Ibid., hal. 78-79.

${ }_{66}$ Thaha Husein, Mir'ah al-Islam..., cet. ke 3, (al-Qahirah: Dar al-Ma'arif, 1998), hal. 10-20.

${ }^{67}$ Ibid., hal.82.
} 
Qur'an menyebut mereka sebagai masyarakat yang suka berdebat. ${ }^{68}$ Lalu bagaimana mungkin masyarakat yang demikian disebut sebagai masyarakat bodoh.

Memang Husien tidak menolak adanya masyarakat yang bodoh di kalangan mereka yang biasa disebut masyarakat baduwih. Namun hal itu merupakan suatu hal yang biasa terjadi di manapun. Menurut Husien ada dua kategori masyarakat pada setiap umat: golongan masyarakat yang tercerahkan yang mempuyai kelebihana dalam bidang sumber daya kemanusiaannya, kecedasan, dan ilmu pengetahuannya. Kedua adalah golongan masyarakat awam yang tidak mempunyai kelebihankelebihana sebagaimana pertama. Yang kedua ini ditunjukkan Al-Qur'an sebagai golongan yang hanya berkemampuan mengikuti apa yang dipegang pemimpinya. Mereka tidak mempunyai kemampuan berfikir secara mandiri sehingga apuas menemukan kebenarannya. ${ }^{69}$

Al-Qur'an juga menceritakan tentang hubungan masyarakat Arab dengan masyarakat luar, seperti Persia dan Romawi. Ini berbeda halnya dengan pandangan apa yang disebut sebagai syi'ir Jahiliyah bahwa mereka adalah masyarakat yang tertutup yang hanya bisa hidup menetap di padang pasir. Mereka tidak mengenal alam luar, sebaliknya alam luar tidak mengetahuinya. Bersamaan dengan itu, para perawi syi'ir kemudian menyatakan bahwa syi'ir Arab tidak terpengaruh oleh duia luar, termasuk romawi dan Persia. Sebaliknya Al-Qur'an menyatakan bahwa masyarakat Arab telah berhubungan dengan dunia luar dalam berbagai bidang, baik dalam politik maupun ekonomi. ${ }^{70}$ Selain itu, ada banyak tradisi Arab pra-Islam yang diadopsi Al-Qur'an dengan diisi muatan baru yang sesuai dengan Islam. ${ }^{71}$ Pengadopsian itu membuktikan bahwa tradisi-tradisi masyarakat pra-Islam memuat sesuatu yang positif, selain sisi negatifnya.

\section{F. Penutup}

Paparan di atas menunjukkan bahwa apa yang disebut syi'ir Jahiliyah bukanlah benar-benar syi'ir yang ditulis para penyair Jahiliyah. Ia dibuat para pemikir di era Islam, khususnya era Abbasiyah yang didorong oleh motivasi-motivasi tertentu,

68 Ibid., hal. 83.

69 Ibid., hal. 83-84.

70 Ibid., hal. 84-85.

71 Khalil Abdul Karim, Syari'ah: Sejarah Perkelahian Pemakanaan, (Yogyakarta: LKiS, 2003); Tosihiku Izutsu, Etika Beragama Dalam Al-Qur'an, terj. Mansuruddin Djoely, (Jakarta: Pustaka Firdaus, cet. 2, 1995), hal. 113-157. 
seperti motivasi politik, agama, fanatisme kebangsaan, kisah, dan perawi. Karena itu, wajar jika syi'ir-syi'ir itu, tegas Thoha Husein, tidak mencerminkan bahasa dan lahjah masyarakat Arab pra-Islam. Tidak pula menunjukkan secara obyektif masyarakat itu. Karena itu, dia menilai, syi'ir-syi'ir itu tidak bisa dijadikan sebagai alat melihat masyarakat Jahiliyah. Yang bisa digunakan hanyalah Al-Qur'an, yang otentisitasnya tidak diragukan lagi.

\section{DAFTAR PUSTAKA}

Ali, Seed Ameer. 1978. Api Islam,sejarah evolusi dan cita-cita Islam dengan Riwayat Hidup Nabi Muhammad S.A.W, terj. H.B. Yassin. Jakarta: PT Bulan Bintang.

Amin, Ahmad. 2002. Duha al-Islam, al-Qahirah: Maktabah al-Usrah, al-Hay'ah alMishriyyah al-Amah li al-Kitab, dan al-A'Mal al-Diniyah.

Descartes, Rene. 1995. Risalah Tentang Metode, terj. Ida Sundari Husen dan Rahayu S. Hidayat. Jakarta: Gramedia.

Ghali, Wail. 1996. "Descartes al-Ghaib an Thaha Husein", dalam Rasa"il Thoba Husein. al-Qahirah: tp.

Gholdziher, Ignaz. 1983. Madzahib al-Tafsir al-Islami, cet. Ke-2. Beirut Libanon: Dar Iqra'.

Hamid al-Kurdi, Rajih Abdul. 1992. Nadlariyatual al-Ma'rifab: baina Al-Qur'an wa al-Falsafah. Riyad: Maktabah al-Muayyad.

Harahap, Syahrin. 1994. Al-Qur'an dan Sekularisasi: Kajian Kritis Terhadap Pemikiran Thaba Husein. Yogyakarta: Tiara Wacana.

Husein, Thaha. 1927. Fi Al-Adab Al-Jahili. al-Qahirah: Dar al-Ma'arif. . 2007. Fi al-Syi'ri al-Jabili. al-Qahirah: Ru'yah. . 1998. Mir'ah al-Islam, cet. Ke-3. al-Qahirah: Dar al-Ma'arif. __. 2003. Janji Sejati, terj. Harits bin Solihin. Yogyakarta: Tinta CV Qolam. Izutsu, Tosihiku. 1995. Etika Beragama Dalam Al-Qur'an, terj. Mansuruddin Djoely. Jakarta: Pustaka Firdaus.

Jansen. 1997. Diskursus Tafsir Al-Qur'an Modern, terj. Hairussalim. Yogayakarta: Tiara Wacana. 
Karim, Khalil Abdul. 2003. Syari'ah: Sejarah Perkelabian Pemakanaan. Yogyakarta: LkiS.

Nur, Muhammad. 2007. Qirar Niyabah fi Qadiyyah kitab Fi si'ri al-Jabili", dalam Tohah Husein, Fi Syiri al-Jahili. al-Qahirah: Ru'yah.

al-Qimni, Sayyid Mahmud. 2004. Nabi Ibrabim: Titik Temu-Titik Tengkar AgamaAgama, terj. Kamran As'ad Irsyadi. Yogyakarta: LkiS.

Qutub, Sayyid. 2004. Keindahan Al-Qur'an yang Menakjubkan: Buku Bantu Memahami Tafsir fi Zhilalil Qur'an, terj. Bahrun Abu Bakar. Jakarta: Rabbani Press.

Ruslani. 2000. Masyarakat dan al-Kitab dan Dialog Antar Agama, Study atas Pemikiran Muhammad Arkoun. Yogyakarta: Yayasan Bentang Budaya, bekerjasama dengan yayasan Adikarya IKAPI dan The Ford Foundation. 